Research Article

\title{
Effect of Design Parameters on Fresh Water Produced from Triangular Basin and Conventional Basin Solar Still
}

\author{
A. Rajendra Prasad, ${ }^{1}$ Ravishankar Sathyamurthy $\mathbb{D}^{2}{ }^{2}$ M. Sudhakar, ${ }^{1}$ B. Madhu, ${ }^{3}$ \\ D. Mageshbabu, ${ }^{3}$ A. Muthu Manokar, ${ }^{4}$ and Ali J. Chamkha $\mathbb{i D}^{5,6}$ \\ ${ }^{1}$ Department of Mechanical Engineering, Sri Sairam Engineering College, Chennai, 600045 Tamil Nadu, India \\ ${ }^{2}$ Department of Mechanical Engineering, KPR Institute of Engineering and Technology, Arasur, Coimbatore, \\ 641407 Tamil Nadu, India \\ ${ }^{3}$ Department of Mechanical Engineering, Velammal Institute of Technology, Chennai, Tamil Nadu, India \\ ${ }^{4}$ Department of Mechanical Engineering, B. S. Abdur Rahman Crescent Institute of Science and Technology, Chennai, \\ 600048 Tamil Nadu, India \\ ${ }^{5}$ Faculty of Engineering, Kuwait College of Science and Technology, Kuwait, Kuwait \\ ${ }^{6}$ Institute of Theoretical and Applied Research (ITAR), Duy Tan University, Hanoi 100000, Vietnam
}

Correspondence should be addressed to Ali J. Chamkha; alichamkha@duytan.edu.vn

Received 19 December 2020; Revised 3 February 2021; Accepted 16 February 2021; Published 2 March 2021

Academic Editor: Hafiz Muhammad Ali

Copyright (c) 2021 A. Rajendra Prasad et al. This is an open access article distributed under the Creative Commons Attribution License, which permits unrestricted use, distribution, and reproduction in any medium, provided the original work is properly cited.

\begin{abstract}
This paper reported the experimental testing of a triangular and conventional basin solar still (TBSS and CBSS). Solar basin and absorber are made of glass and a polyethylene cover, respectively, with an area of $0.25 \mathrm{~m}^{2}$. Square and triangular absorber with the same area of $0.25 \mathrm{~m}^{2}$ with square and triangular glass cover for condensation was fixed. Experimentations were conducted during the month of December 2018, and different natural criteria such as intensity, wind speed, and surrounding ambient temperatures were considered. Also, the modified model was compared to the CBSS on its performance and efficiency characteristics. The experimental results also revealed that the temperature of the water inside the TBSS was higher as compared with that of the CBSS. The daily yield obtained from CBSS and TBSS was found to be 2.7 and $3.2 \mathrm{~kg} / \mathrm{m}^{2}$, respectively. Also, the daily efficiency of the TBSS was improved by $11.36 \%$ than the CBSS.
\end{abstract}

\section{Introduction}

Renewables appear to be the one of the source which is inexhaustible, clean, ecofriendly, and cost economic. Also, it appears to be the competitive energy among the other nonrenewable energy sources. Due to their abundance and its potential to use in the globe, they differ from the use of fossil fuel. Renewables will not even produce any kind of greenhouse gases which normally affect the climate which includes the reduction in annual rainfall and increased ambient temperature [1-4].
The utilization of solar energy in the distillation process appears to be an economical method to produce fresh water [5-8]. Manokar et al. [9] reviewed the different types of techniques employed in pyramidal solar still (PSS) for fresh water improvement. The different heat exchange mechanism employed in solar still for enhanced fresh water was reviewed by Kabeel et al. [10]. Similarly, Sathyamurthy et al. [11] surveyed the different geometries employed in cover and absorber of solar still for enhanced yield. The factors that affect the performance of PSS with a triangular basin and cover were experimentally studied by Sathyamurthy 
et al. [12]. Two different parameters, namely controlling the depth of water and cover cooling techniques, were employed to achieve optimum yield. Essa et al. [13] studied a solar still and augmented the yield using a coffee-based colloid. The use of acrylic material as cover material in the PSS was analyzed by Manokar et al. [14].

Kumar et al. [15] used a double collector cover in the PSS. Their results exhibited that double collector cover reduces the thermal efficiency of the PSS as the air gap between the collector cover increased the cover temperature. Nayi [16] made a comprehensive review of the PSS. Experimental studies on the PSS with phase change materials (PCM) were carried out by Sathyamurthy et al. [17, 18]. Kumar et al. [19, 20] carried out theoretical and experimental studies on PSS integrated with an inclined solar still for enhancing fresh water. Kabeel et al. [21] used $\mathrm{TiO}_{2}$ nanoparticles in black paints and coated in the absorber material of the triangular PSS. On the same PSS, Nagarajan et al. [22] theoretically studied the effect of glass cooling using a DC powered fan.

The performance of triangular solar still (TSS) in two different directions was experimentally analyzed by RubioCerda et al. [23]. It was reported that the performance of the TSS at glass cover facing the east-west direction was higher as compared to the TSS at glass cover facing northsouth direction. Varying water depths in the TSS were reported by Ahsan et al. [24]. The maximum yield of 1.6 and $1.55 \mathrm{~kg} / \mathrm{m}^{2}$ was obtained from water depth of 1.5 and $2.5 \mathrm{~cm}$, respectively. A comparison between PSS and CSS was hypothetically studied by Fath et al. [25]. The annual yield produced from the CSS was $1532.7 \mathrm{~L}$ and PSS was $1510.5 \mathrm{~L}$. It was reported that both CSS and PSS produced the nearly same daily yield of about $2.6 \mathrm{~L}$. The performance of the PSS using fan was augmented the yield by $25 \%$ as compared to the conventional PSS by Taamneh and Taamneh [26]. The PSS with a fan has produced the maximum yield of $3 \mathrm{~kg}$ per day, whereas PSS without fan has produced a maximum yield of $2.5 \mathrm{~L}$ per day. Kabeel et al. [27] made a comparative study of conventional PSS and modified PSS basin with V-corrugated absorber surface and PCM. It was reported that modified PSS with PCM produced a daily yield of $6.6 \mathrm{~kg}$, and conventional PSS has a daily yield of 3.5 L. Abdelal and Taamneh [28] introduced a novel composite absorber plate integrated PSS. It was reported that PSS with 5\% CNT-coated plate has a maximum daily production of $3.3 \mathrm{~kg} / \mathrm{m}^{2}$, whereas the black painted plate has yield of $1.73 \mathrm{~kg} / \mathrm{m}^{2}$. Various existing solar still designs such as concave [29], spherical [30], hemispherical [31, 32], vertical [31-36], inverted absorber [37-40], tubular [41], pyramid [42], inclined [43-45], and hybrid solar still [46] are reviewed.

From the various review of literature, it is found that the use of triangular basin/absorber and single-slope triangular cover is not extensively studied. Various criteria such as water temperature, glass temperature, yield, evaporative, and convective heat transfer coefficient (EHTC and CHTC) have been studied in detail from the TBSS and CBSS. The present study is aimed at improving the fresh water produced from a triangular basin with a single-slope arrangement. An

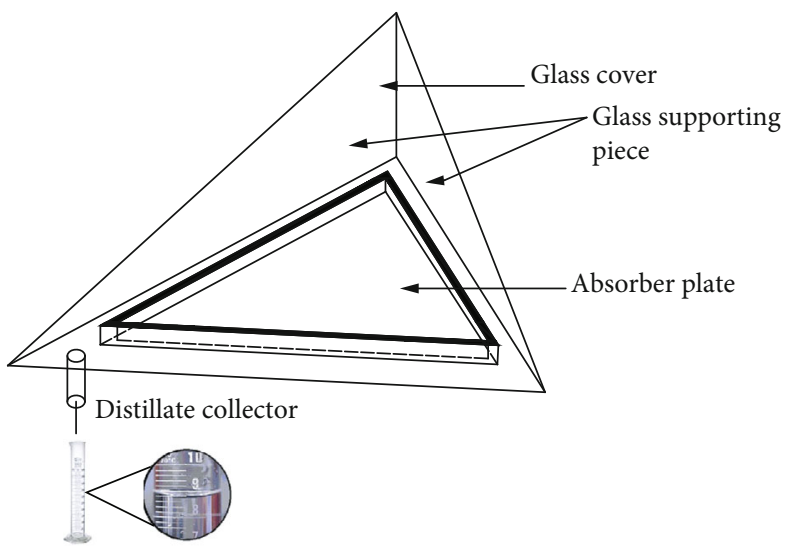

FIGURE 1: Graphical representation of TBSS.

experimental investigation is carried out to study the obtained fresh water produced from the modified absorber and condensing cover of the TBSS.

\section{Experimentation}

Figure 1 shows the graphical representation of the TBSS with an absorber plate made of a triangular section. Figure 2 shows the schematic diagram of the CBSS and TBSS. It consists of a triangular basin with an area of $0.25 \mathrm{~m}^{2}$. The dimensions of the conventional basin type solar still are $0.5 \mathrm{~m}$ long and $0.5 \mathrm{~m}$ wide with higher end wall height of $0.2 \mathrm{~m}$. Similarly, to have equivalent basin area, a triangular basin with sides of $0.57 \mathrm{~m}$ each forms a equilateral triangle, and the basin height is $0.2 \mathrm{~m}$. Two triangular supporting pieces are kept vertical in the absorber, while the cover material is made of polyethylene sheet, which transmits the solar radiance. The sea water is fed into the absorber using a plastic hose, and the flow is controlled using a flow control valve. The evaporated water from the absorber gets condensed in the cover and glides through the smooth inclined surface to the distillate collector and collected in a calibrated flask. Insulation are provided at the bottom and side walls of the solar still to prevent the loss of heat. For comparison and experimental validation, a CBSS with a basin area of $0.25 \mathrm{~m}^{2}$ is fabricated and tested for the same outdoor experimental condition. The flow of sea water into the basin is under control using a control valve. At each interval of evaporation from the upper surface of the water, fresh sea water is fed into the basin to maintain the stable water depth. The whole experiment is fabricated and researched in conditions of Chennai, India. Testing is conducted from 8 a.m. to 6 p.m. during the month of December 2018, while the covers of TBSS and CBSS are facing south direction. On a triangular and conventional basin solar still, four sensors each on the basic elements are placed, and the average values are taken. The water depth inside the TBSS and CBSS is measured on an hourly basis, and sea water is feed into the basin for maintaining stable water depth. Table 1 shows the details of instruments, range, accuracy, and error. The elemental temperatures of the TBSS and CBSS, namely, water, glass, and basin temperature, are measured using PT100 type thermocouple, whereas the wind 


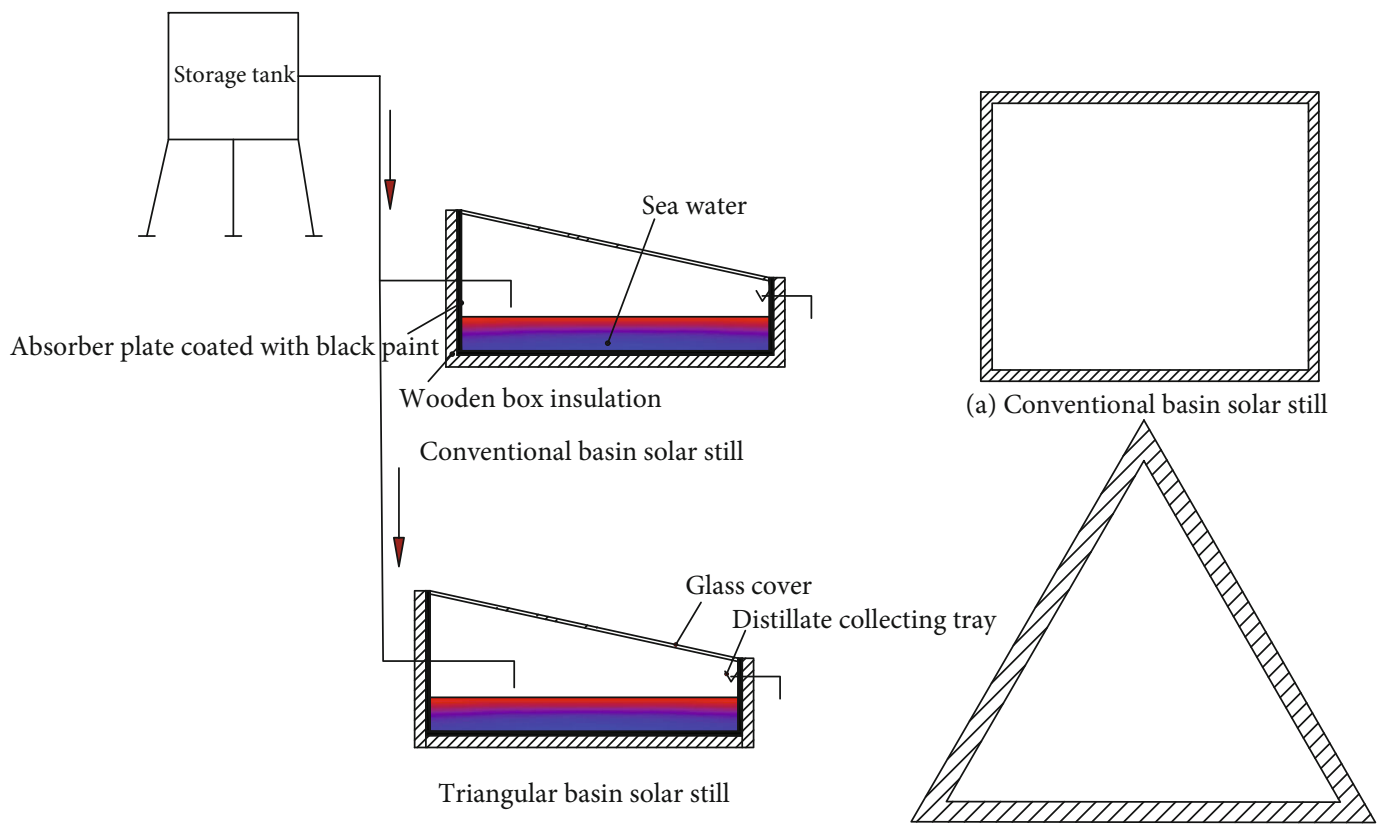

(a) Triangular basin solar still

Figure 2: Schematic diagram of conventional and triangular basin solar still.

TABle 1: Range, accuracy, error, and instruments used in the study.

\begin{tabular}{lccc}
\hline Instrument & Range & Accuracy & \\
\hline Temperature sensor (PT-100 type) & $0-500^{\circ} \mathrm{C}$ & $\pm 0.1^{\circ} \mathrm{C}$ & Error \\
Distillate collecting flask & $0-2000 \mathrm{ml}$ & $\pm 10 \mathrm{ml}$ & $\pm 1.5 \%$ \\
Wind velocity meter & $0-45 \mathrm{~m} / \mathrm{s}$ & $\pm 0.1 \mathrm{~m} / \mathrm{s}$ & $\pm 1.5 \%$ \\
Solar power meter & $0-3500 \mathrm{~W} / \mathrm{m}^{2}$ & $\pm 10 \mathrm{~W} / \mathrm{m}^{2}$ & $\pm 3 \%$ \\
\hline
\end{tabular}

velocity and solar radiance are measured using anemometer and solar power meter, respectively. On an hourly basis, temperatures, solar intensity, and distillate collected are measured.

The daily efficiency of TBSS and CBSS is the ratio of the product of latent heat of vaporization and the amount of accumulated potable water produced to the accumulated solar intensity for the entire day.

\section{Uncertainty}

The instruments used in the experiments produce some possible errors which is determined in the form of uncertainty. The uncertainties produced during the experiments from the instruments is tabulated in Table 1. It is defined as the ratio of smallest amount to the least value of output. The uncertainty produced by the calibrated flask in collecting the distilled water depends on the amount of water collected in the flask. It is mathematically expressed as

$$
R_{m}=\sqrt{\left(\frac{\partial m}{\partial h} R_{h}\right)^{2}}
$$

For determining the uncertainty of TBSS and CBSS daily efficiency, the amount of water collected in the calibrated flask and solar radiation falling on the glass surface and is mathematically expressed as

$$
R_{\eta}=\sqrt{\left(\frac{\partial \eta}{\partial m} R_{m}\right)^{2}+\left(\frac{\partial \eta}{\partial I(t)} R_{I(t)}\right)^{2}} .
$$

Using Equation (1), the uncertainties of distilled water collected from the calibrated flask, solar radiation, wind velocity, and temperature were calculated as $1.5,3.5,3$, and $1.5 \%$, respectively. Similarly, using (2), the calculated uncertainty of daily efficiency is found as $2.1 \%$.

\section{Results and Discussion}

The fluctuation in solar intensity, basin, water, and glass temperature of the CBSS and TBSS is shown in Figure 3. The experiments were conducted for the December 2018 (30 days), and the best readings are taken for the analysis. The improvement in performance and efficiency of renewable energy system depends on external input parameters such as solar intensity, ambient temperature, and wind velocity. 

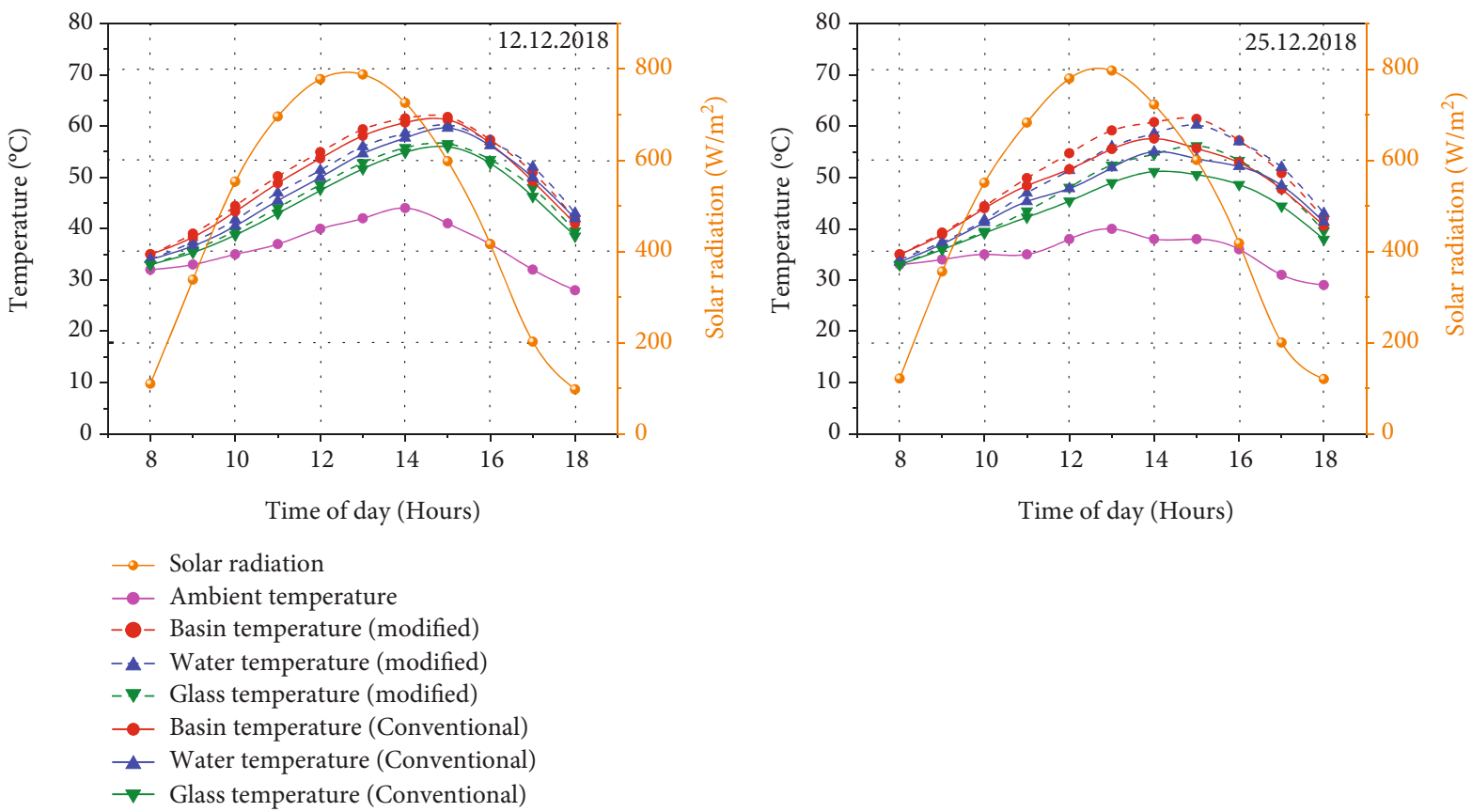

FIGURE 3: Variations in solar intensity, basin, water, and glass temperature of CBSS and TBSS on 12.12.2018 and 25.12.2018.
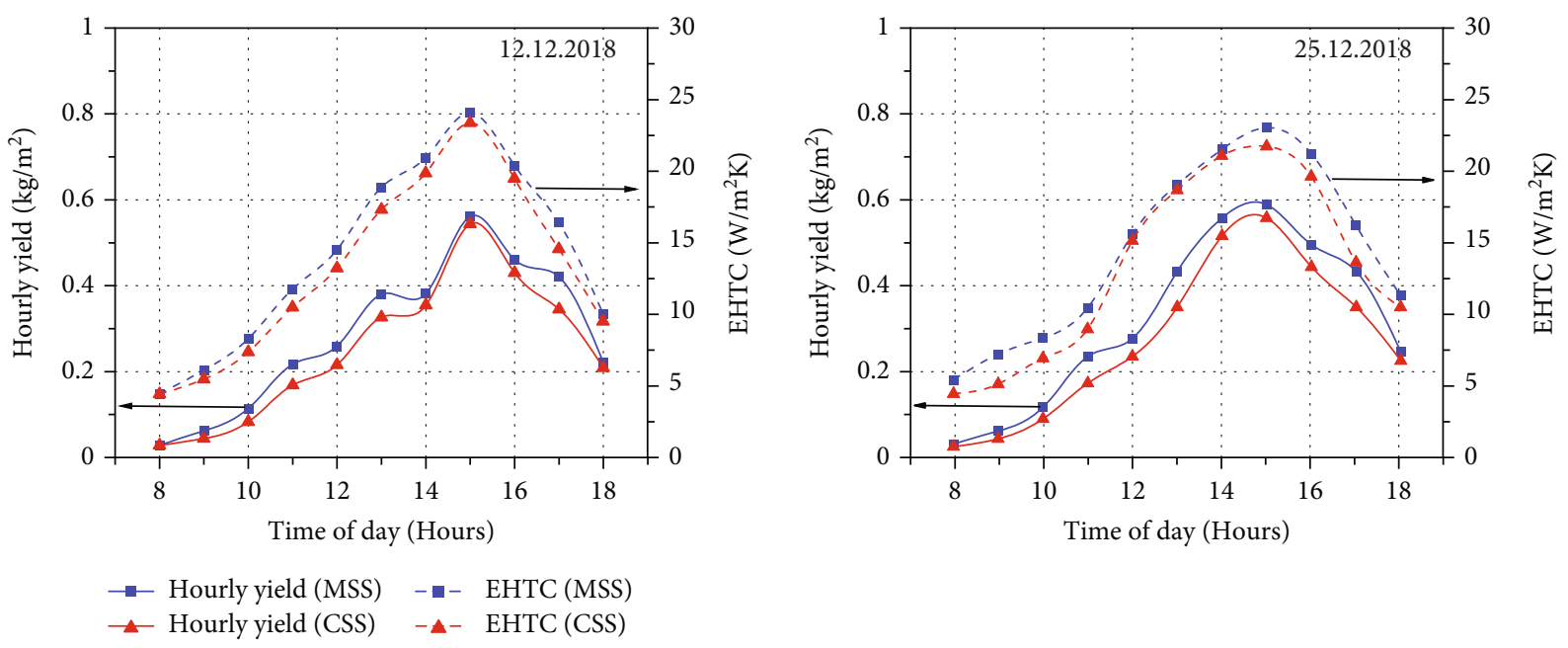

Figure 4: Variations in yield and EHTC from CBSS and TBSS.

With continuous solar intensity as heat input, the elements of the TBSS and CBSS such as water, glass, and basin temperature rise. As time varies, the solar intensity varies by reaching its peak during the midnoon. The whole experiment was conducted during the bright sky condition. The peak solar radiation recorded during the experiments on 12.12.2018 and 25.12.2018 were 778 and $797 \mathrm{~W} / \mathrm{m}^{2}$ while the ambient temperature recorded for the corresponding experiments was 42 and $40^{\circ} \mathrm{C}$, respectively. It can be noticed that the maximum temperature occurs at 15:00 Hrs. The maximum temperature of the water using TBSS is found as $60.4^{\circ} \mathrm{C}$, whereas the temperature of the water using conventional is $58.3^{\circ} \mathrm{C}$. The water temperature peaks at 15:00 Hrs; as the heat energy is stored in the water as sensible heat and during the lower sun shine hours, the energy is liberated. Also, it is clearly evident that the maximum exposure area of water with solar radiation is the cause for higher temperature in the modified solar still with triangular basin than conventional basin type solar still. Similarly, the cover glass temperature of TBSS is higher as compared to that of CBSS. Due to higher evaporation from the basin, the vapor gets accumulated in the glass cover which possibly increase the temperature of cover from the modified triangular basin solar still. The maximum temperature difference between water and glass is found as $3.6^{\circ} \mathrm{C}$ and $3.2^{\circ} \mathrm{C}$ for TBSS and CBSS.

The peak glass temperature of the TBSS and CBSS are found as 56.1 and $50.5^{\circ} \mathrm{C}$ on 25.12 .2018 , respectively. There is a maximum temperature difference between water and 


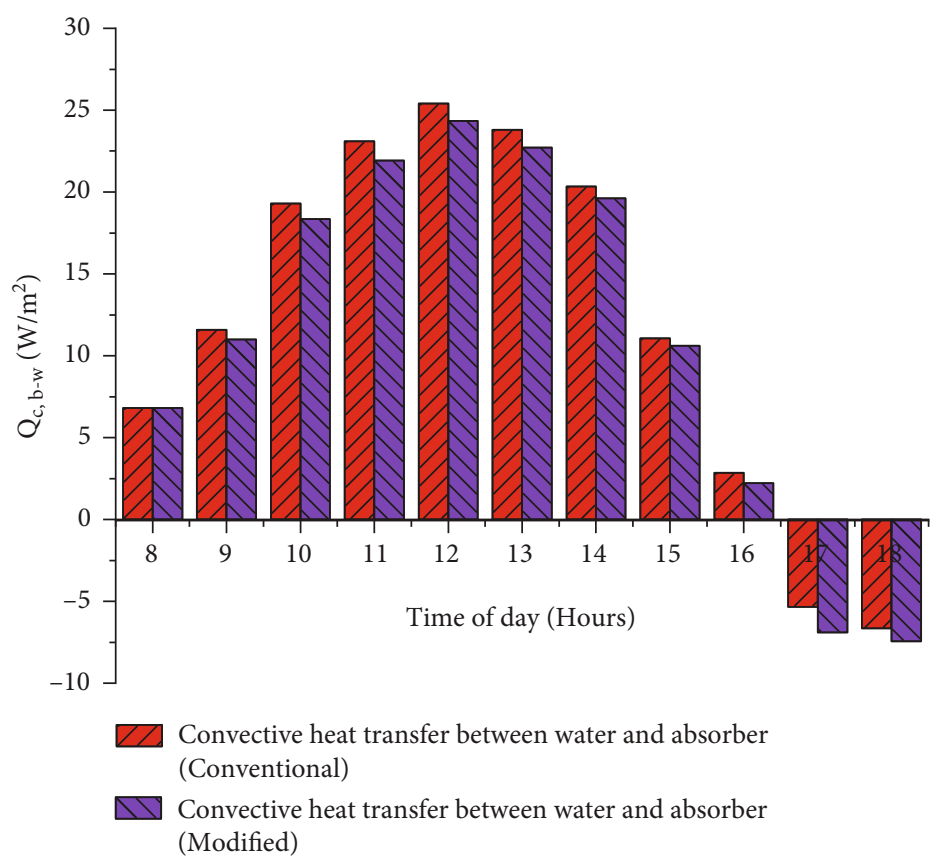

FIgURE 5: Variations in CHTC between water and basin of CBSS and TBSS.

TABLE 2: Comparison of yield and thermal efficiency from the CBSS and TBSS.

\begin{tabular}{|c|c|c|c|c|c|c|}
\hline \multirow[b]{2}{*}{ Date of experiment } & \multicolumn{2}{|c|}{ Daily yield $\left(\mathrm{kg} / \mathrm{m}^{2}\right)$} & \multicolumn{2}{|c|}{ Daily efficiency (\%) } & \multirow{2}{*}{$\begin{array}{c}\text { Total solar } \\
\text { radiation } \\
\left(\mathrm{W} / \mathrm{m}^{2}\right)\end{array}$} & \multirow{2}{*}{$\begin{array}{l}\text { Improvement } \\
\text { in yield (\%) }\end{array}$} \\
\hline & MSS & CSS & MSS & CSS & & \\
\hline 12.12 .2018 & 3.24 & 2.82 & 38.28 & 33.32 & 5303 & 12.96 \\
\hline 15.12 .2018 & 3.35 & 2.84 & 38.79 & 32.88 & 5412 & 15.22 \\
\hline 19.12.2018 & 3.12 & 2.74 & 37.24 & 32.70 & 5250 & 12.17 \\
\hline 25.12.2018 & 3.41 & 2.91 & 39.24 & 33.49 & 5445 & 14.66 \\
\hline
\end{tabular}

glass on 25.12.2018 using TBSS, and CBSS is found as 4 and $3.1^{\circ} \mathrm{C}$, respectively. The increase in temperature of the water is due to the maximum absorption of solar radiance with the modified cover surface, which enhanced the evaporation and condensation rate inside the closed chamber. During the experiments, it is found that the elemental temperatures, such as basin, water, and glass, are higher using the TBSS compared to that of CBSS.

Similarly, the variations in yield and EHTC using the correlation from Appendix of the CBSS and TBSS for two different experimental days are shown in Figure 4. It can be seen that the evaporation rate is enhanced using the modified absorber geometry inside the TBSS. The maximum EHTC from the TBSS and CBSS are found as 24.3 and $23.2 \mathrm{~W} / \mathrm{m}^{2} \mathrm{~K}$, respectively. On the other hand, the maximum distilled water produced from the TBSS and CBSS is found to be 0.56 and $0.54 \mathrm{~kg} / \mathrm{m}^{2}$, respectively. The increase in freshwater yield is due to the effect of higher evaporation with higher water temperature within the modified basin. There is an increase of about $3.7 \%$ in the maximum productivity, and an increase of about $12.96 \%$ is observed in the total productivity of freshwater produced. On average, freshwater produced from the TBSS is improved by $12 \%$ than the CBSS.
The increase in output is due to the effect of a lower $\mathrm{CHTC}$ rate between water and basin (Figure 5). The CHTC between water and basin is higher in the case of the conventional basin, whereas, with the modified basin, the CHTC reduces. During the absence of solar radiation, the $\mathrm{CHTC}$ has a negative impact on the modified basin as the rate of CHTC is higher as compared to that of the conventional basin. A comparison of daily productivity and daily efficiency of the TBSS and CBSS during the experimental days is tabulated in Table 2. It is known that the daily yield from the TBSS and CBSS was found as 3.12-3.41 and 2.74$2.91 \mathrm{~kg} / \mathrm{m}^{2}$, respectively. There is an improvement in yield of about $12.96-15.22 \%$ using the TBSS than the CBSS. It is also seen that the daily efficiency of the CBSS using a square absorber is lower as compared to that of TBSS using a triangular absorber. The daily efficiency of TBSS and CBSS ranges from 37.24 to 39.24 and from 32.7 to $33.49 \%$, respectively.

The various published work related to our testing is provided in Table 3 . From the table, it has been identified that PSS integrated with inclined solar still provided the maximum yield of $7.52 \mathrm{~kg} / \mathrm{m}^{2}$, and triangular PSS coated with $\mathrm{TiO}_{2}$ nanoparticle has a yield of $6.6 \mathrm{~kg} / \mathrm{m}^{2}$. According to 
TABLE 3: Comparison of present testing with previously published work.

\begin{tabular}{|c|c|c|c|c|}
\hline S. No & Author name & Experimentation & Yield & Location \\
\hline 1 & Kumar et al. $[19,20]$ & PSS integrated with an inclined solar still & $7.52 \mathrm{~kg} / \mathrm{m}^{2}$ & Chennai, India \\
\hline 2 & Kabeel et al. [21] & Triangular PSS coated with $\mathrm{TiO} 2$ nanoparticle & $6.6 \mathrm{~kg} / \mathrm{m}^{2}$ & Chennai, India \\
\hline 3 & Ahsan et al. [24] & Experimentation on TSS by varying water depth & $1.6 \mathrm{~kg} / \mathrm{m}^{2}$ & Japan \\
\hline 4 & Taamneh and Taamneh [26] & The PSS with fan & $3 \mathrm{~L}$ & Jordan \\
\hline 5 & Kabeel et al. [27] & $\begin{array}{c}\text { Modified PSS basin with V-corrugated absorber surface } \\
\text { and PCM }\end{array}$ & $6.6 \mathrm{~kg} / \mathrm{m}^{2}$ & Tanta, Egypt \\
\hline 6 & Abdelal and Taamneh [28] & Novel composite absorber plate integrated PSS & $3.3 \mathrm{~kg} / \mathrm{m}^{2}$ & Jordan \\
\hline 7 & Kabeel et al. [47] & Tubular solar still using NPCM & $5.62 \mathrm{~kg} / \mathrm{m}^{2}$ & Chennai, India \\
\hline 8 & Kabeel [29] & Concave wick & $4.1 \mathrm{~L} / \mathrm{m}^{2}$ & Tanta, Egypt \\
\hline 9 & Dhiman [30] & Spherical solar still & $2.75 \mathrm{~kg} / \mathrm{m}^{2}$ & India \\
\hline 10 & Ismail [48] & Hemispherical solar still transportable type & $5.7 \mathrm{~L} / \mathrm{m}^{2}$ & Saudi Arabia \\
\hline 11 & Arunkumar et al. [49] & Hemispherical solar still & $4200 \mathrm{~mL} / \mathrm{m}^{2}$ & Coimbatore, India \\
\hline 12 & $\begin{array}{c}\text { Minasian and } \\
\text { Al-Karaghouli [33] }\end{array}$ & Floating vertical solar still & $5000 \mathrm{~mL} / \mathrm{m}^{2}$ & Baghdad \\
\hline 13 & Boukar and Harmim [31] & Vertical solar still & $2.3 \mathrm{~kg} / \mathrm{m}^{2}$ & Adrar \\
\hline 14 & Tanaka [32] & Multi effect vertical diffusion solar still & $13.3 \mathrm{~kg} / \mathrm{m}^{2}$ & Fukuoka, Japan \\
\hline 16 & Boukar and Harmim [35] & One sided vertical solar still & $1.2 \mathrm{~kg} / \mathrm{m}^{2}$ & Adrar, Algeria \\
\hline 17 & El-Sebaii $[36]$ & Vertical solar still & $4.2 \mathrm{~kg} / \mathrm{m}^{2}$ & Tanta, Egypt \\
\hline 18 & $\begin{array}{l}\text { Abdul-Wahab and } \\
\text { Al-Hatmi [37] }\end{array}$ & Inverted absorber solar still with refrigeration cycle & $10.08 \mathrm{~kg} /$ day & $\begin{array}{c}\text { Muscat, Sultanate } \\
\text { of Oman }\end{array}$ \\
\hline 19 & $\begin{array}{l}\text { Abdul-Wahab and } \\
\text { Al-Hatmi [38] }\end{array}$ & Inverted absorber solar still with refrigeration cycle & $10.08 \mathrm{~kg} /$ day & $\begin{array}{c}\text { Muscat, Sultanate } \\
\text { of Oman }\end{array}$ \\
\hline 20 & Present study & TBSS & $3.2 \mathrm{~kg} / \mathrm{m}^{2}$ & Chennai, India \\
\hline
\end{tabular}

Ahsan et al. [24], TSS produced a yield of $1.6 \mathrm{~kg} / \mathrm{m}^{2}$, but our work has produced maximum productivity of $3.2 \mathrm{~kg} / \mathrm{m}^{2}$. The present TBSS has produced 50\% higher productivity as compared to that of Ahsan et al. [24].

\section{Conclusions}

The present experimental investigation was conducted in the climatic situation of Chennai, India, and the following conclusions were arrived from the experimental results:

(i) Water temperature from the TBSS with the triangular basin was increased by about $12 \%$ when compared to the CBSS

(ii) The maximum total yield produced from the TBSS and CBSS was found to be 3.24 and $2.82 \mathrm{~kg} / \mathrm{m}^{2}$ while the total productivity using modified absorber was improved by $12.96 \%$ than CBSS

(iii) The increased yield of freshwater was higher in the case of TBSS, and it was mainly due to its exposure area and the condensing cover area with the solar radiance

(iv) The daily thermal efficiency of the overall system using TBSS and CBSS was found as 39.24 and $33.29 \%$, respectively.

\section{Appendix}

The EHTC from saline water to glass is calculated by $[50,51]$

$$
h_{e, w-g}=16.273 \times 10^{-3} \times h_{c, w-g}\left[\frac{P_{w}-P_{g i}}{T_{b . w}-T_{g i}}\right] \text {. }
$$

The CHTC from the saline water to the glass is calculated by $[50,51]$

$$
h_{c, w-g}=0.884\left[\left(T_{b . w}-T_{g i}\right)+\frac{\left(P_{w}-P_{g i}\right)\left(T_{b . w}+273\right)}{\left(268.9 \times 10^{-3}-P_{w}\right)}\right] \text {. }
$$

Partial vapor pressure at the water is calculated by $[50,51]$

$$
P_{w}=\exp \left(25.317-\left(\frac{5144}{273+T_{b . w}}\right)\right)
$$

Partial vapor pressure at the glass is calculated by $[50,51]$

$$
P_{g i}=\exp \left(25.317-\left(\frac{5144}{273+T_{g i}}\right)\right)
$$


The energy efficiency of the TBSS and CBSS is estimated as $[50,51]$

$$
\eta_{\text {passive }}=\frac{\sum \dot{m}_{e w} \times L}{\sum I(t) A_{s} \times 3600} \times 100
$$

where $h$ is the latent heat of vaporization $(\mathrm{kJ} / \mathrm{kg})$ and $I(t)$ is the solar intensity $\left(\mathrm{W} / \mathrm{m}^{2}\right)$.

The latent heat of vaporization is mathematically expressed by

$$
\begin{aligned}
h_{f g}= & 10^{3}\left[2501.9-2.40706 T_{w}+1.192217 \times 10^{-3} T_{w}\right. \\
& \left.-1.5863 \times 10^{-5} T_{w}\right],
\end{aligned}
$$

where $T_{\mathrm{w}}$ is the temperature of water $\left({ }^{\circ} \mathrm{C}\right)$.

\section{Nomenclature}

TBSS: Triangular basin solar still

CBSS: Conventional basin solar still

PSS: Pyramidal solar still

EHTC: Evaporative heat transfer coefficient

CHTC: Convective heat transfer coefficient

TSS: Triangular solar still

\section{Data Availability}

Will be made available on request.

\section{Conflicts of Interest}

The authors declare that they have no conflicts of interest.

\section{References}

[1] A. Vedrtnam, M. P. Upadhyay, and K. Kalauni, "Experimental and theoretical studies of the heat transfer characteristics of the lab-scale sensible heat storage system," International Journal of Energy for a Clean Environment, vol. 20, no. 2, pp. 167193, 2019.

[2] N. V. Ogueke, M. C. Njoku, and E. E. Anyanwu, "Design, construction, and testing of a cylindrical solar water heater," International Journal of Energy for a Clean Environment, vol. 10, no. 1-4, pp. 57-72, 2009.

[3] H. Agrawal, V. Yadav, Y. Kumar, and A. Yadav, "Comparison of experimental data for sensible and latent heat storage materials for late-evening cooking based on a dish-type solar cooker," International Journal of Energy for a Clean Environment, vol. 15, no. 1, pp. 47-72, 2014.

[4] A. Kumar and A. Yadav, "Experimental investigation of a desiccant air conditioning system based on solar-powered composite desiccant bed heat exchanger," International Journal of Energy for a Clean Environment, vol. 18, no. 1, pp. 79-97, 2017.

[5] B. Madhu, B. E. Balasubramanian, A. E. Kabeel et al., "Experimental investigation on the effect of sensible heat energy storage in an inclined solar still with baffles," Desalination and Water Treatment, vol. 116, pp. 49-56, 2018.

[6] R. Sathyamurthy and E. El-Agouz, "Experimental analysis and exergy efficiency of a conventional solar still with Fresnel lens and energy storage material," Heat Transfer-Asian Research, vol. 48, no. 3, pp. 885-895, 2019.

[7] G. B. Balachandran, P. W. David, A. B. P. Vijayakumar, A. E. Kabeel, M. M. Athikesavan, and R. Sathyamurthy, "Enhancement of PV/T-integrated single slope solar desalination still productivity using water film cooling and hybrid composite insulation," Environmental Science and Pollution Research, vol. 27, no. 26, pp. 32179-32190, 2019.

[8] A. Khechekhouche, B. Benhaoua, A. M. Manokar, A. E. Kabeel, and R. Sathyamurthy, "Exploitation of an insulated air chamber as a glazed cover of a conventional solar still," Heat Transfer-Asian Research, vol. 48, no. 5, pp. 1563$1574,2019$.

[9] A. M. Manokar, Y. Taamneh, A. E. Kabeel, R. Sathyamurthy, D. P. Winston, and A. J. Chamkha, "Review of different methods employed in pyramidal solar still desalination to augment the yield of freshwater," Desalination and Water Treatment, vol. 136, pp. 20-30, 2018.

[10] A. E. Kabeel, T. Arunkumar, D. C. Denkenberger, and R. Sathyamurthy, "Performance enhancement of solar still through efficient heat exchange mechanism - a review," Applied Thermal Engineering, vol. 114, pp. 815-836, 2017.

[11] R. Sathyamurthy, D. G. Harris Samuel, P. K. Nagarajan, and T. Arunkumar, "Geometrical variations in solar stills for improving the fresh water yield-a review," Desalination and Water Treatment, vol. 57, no. 45, pp. 21145-21159, 2016.

[12] R. Sathyamurthy, H. J. Kennady, P. K. Nagarajan, and A. Ahsan, "Factors affecting the performance of triangular pyramid solar still," Desalination, vol. 344, pp. 383-390, 2014.

[13] F. A. Essa, A. H. Elsheikh, A. A. Algazzar et al., "Eco-friendly coffee-based colloid for performance augmentation of solar stills," Process Safety and Environmental Protection, vol. 136, pp. 259-267, 2020.

[14] A. Muthu Manokar, Y. Taamneh, A. E. Kabeel et al., "Effect of water depth and insulation on the productivity of an acrylic pyramid solar still - an experimental study," Groundwater for Sustainable Development, vol. 10, p. 100319, 2020.

[15] S. A. Kumar, P. S. Mohan Kumar, R. Sathyamurthy, and A. M. Manokar, "Experimental investigation on pyramid solar still with single and double collector cover-comparative study," Heat Transfer-Asian Research, vol. 49, no. 1, pp. 103-119, 2020.

[16] K. Nayi and K. V. Modi, "Pyramid solar still: a comprehensive review," Renewable and Sustainable Energy Reviews, vol. 81, pp. 136-148, 2018.

[17] R. Sathyamurthy, P. K. Nagarajan, H. Kennady, T. S. Ravikumar, V. Paulson, and A. Ahsan, "Enhancing the heat transfer of triangular pyramid solar still using phase change material as storage material," Frontiers in Heat and Mass Transfer (FHMT), vol. 5, no. 1, p. 3, 2014.

[18] R. Sathyamurthy, P. K. Nagarajan, J. Subramani, D. Vijayakumar, and K. M. A. Ali, "Effect of water mass on triangular pyramid solar still using phase change material as storage medium," Energy Procedia, vol. 61, pp. 2224-2228, 2014.

[19] P. N. Kumar, D. G. Harris Samuel, P. K. Nagarajan, and R. Sathyamurthy, "Theoretical analysis of a triangular pyramid solar still integrated to an inclined solar still with baffles," International Journal of Ambient Energy, vol. 38, no. 7, pp. 694-700, 2016.

[20] P. N. Kumar, A. M. Manokar, B. Madhu et al., "Experimental investigation on the effect of water mass in triangular pyramid 
solar still integrated to inclined solar still," Groundwater for Sustainable Development, vol. 5, no. 2, pp. 29-234, 2017.

[21] A. E. Kabeel, R. Sathyamurthy, S. W. Sharshir et al., "Effect of water depth on a novel absorber plate of pyramid solar still coated with $\mathrm{TiO}_{2}$ nano black paint," Journal of Cleaner Production, vol. 213, pp. 185-191, 2019.

[22] P. K. Nagarajan, S. A. El-Agouz, T. Arunkumar, and R. Sathyamurthy, "Effect of forced cover cooling technique on a triangular pyramid solar still," International Journal of Ambient Energy, vol. 38, no. 6, pp. 597-604, 2016.

[23] E. Rubio-Cerda, M. A. Porta-Gándara, and J. L. FernandezZayas, "Thermal performance of the condensing covers in a triangular solar still," Renewable Energy, vol. 27, no. 2, pp. 301-308, 2002.

[24] A. Ahsan, M. Imteaz, U. A. Thomas, M. Azmi, A. Rahman, and N. N. Daud, "Parameters affecting the performance of a low cost solar still," Applied Energy, vol. 114, pp. 924-930, 2014.

[25] H. E. Fath, M. El-Samanoudy, K. Fahmy, and A. Hassabou, "Thermal-economic analysis and comparison between pyramid-shaped and single- slope solar still configurations," Desalination, vol. 159, no. 1, pp. 69-79, 2003.

[26] Y. Taamneh and M. M. Taamneh, "Performance of pyramidshaped solar still: experimental study," Desalination, vol. 291, pp. 65-68, 2012.

[27] A. E. Kabeel, M. A. Teamah, M. Abdelgaied, and G. B. A. Aziz, "Modified pyramid solar still with v-corrugated absorber plate and PCM as a thermal storage medium," Journal of Cleaner Production, vol. 161, pp. 881-887, 2017.

[28] N. Abdelal and Y. Taamneh, "Enhancement of pyramid solar still productivity using absorber plates made of carbon fiber/CNT-modified epoxy composites," Desalination, vol. 419, pp. 117-124, 2017.

[29] A. E. Kabeel, "Performance of solar still with a concave wick evaporation surface," Energy, vol. 34, no. 10, pp. 1504-1509, 2009.

[30] N. K. Dhiman, "Transient analysis of a spherical solar still," Desalination, vol. 69, no. 1, pp. 47-55, 1989.

[31] M. Boukar and A. Harmim, "Parametric study of a vertical solar still under desert climatic conditions," Desalination, vol. 168, pp. 21-28, 2004.

[32] H. Tanaka, "Experimental study of vertical multiple-effect diffusion solar still coupled with a flat plate reflector," Desalination, vol. 249, no. 1, pp. 34-40, 2009.

[33] A. N. Minasian and A. A. Al-Karaghouli, "Floating vertical solar still for desalination of marsh water," Renewable Energy, vol. 2, no. 6, pp. 631-635, 1992.

[34] M. Boukar and A. Harmim, "Development and testing of a vertical solar still," Desalination, vol. 158, no. 1-3, p. 179, 2003.

[35] M. Boukar and A. Harmim, "Performance evaluation of a onesided vertical solar still tested in the Desert of Algeria," Desalination, vol. 183, no. 1-3, pp. 113-126, 2005.

[36] A. A. El-Sebaii, "Parametric study of a vertical solar still," Energy Conversion and Management, vol. 39, no. 13, pp. 1303-1315, 1998.

[37] S. A. Abdul-Wahab and Y. Y. Al-Hatmi, "Study of the performance of the inverted solar still integrated with a refrigeration cycle," Procedia engineering, vol. 33, pp. 424-434, 2012.

[38] S. A. Abdul-Wahab and Y. Y. Al-Hatmi, "Performance evaluation of an inverted absorber solar still integrated with a refrigeration cycle and an inverted absorber solar still," Energy for Sustainable Development, vol. 17, no. 6, pp. 642-648, 2013.
[39] S. A. Abdul-Wahab, A. M. Al-Damkhi, H. Al-Hinai, R. Dev, and G. N. Tiwari, "Experimental study of an inverted absorber solar still," Desalination and Water Treatment, vol. 19, no. 1-3, pp. 249-254, 2012.

[40] E. Shanazari and R. Kalbasi, "Improving performance of an inverted absorber multi-effect solar still by applying exergy analysis," Applied Thermal Engineering, vol. 143, pp. 1-10, 2018.

[41] M. M. Thalib, A. M. Manokar, F. A. Essa, N. Vasimalai, R. Sathyamurthy, and F. P. Garcia Marquez, "Comparative study of tubular solar stills with phase change material and nano-enhanced phase change material," Energies, vol. 13, no. 15, p. 3989, 2020.

[42] A. M. Manokar, D. P. Winston, R. Sathyamurthy, A. E. Kabeel, and A. R. Prasath, "Experimental investigation on pyramid solar still in passive and active mode," Heat and Mass Transfer, vol. 55, no. 4, pp. 1045-1058, 2019.

[43] A. M. Manokar, M. Vimala, D. P. Winston, R. Sathyamurthy, and A. E. Kabeel, "Effect of Insulation on Energy and Exergy Effectiveness of a Solar Photovoltaic Panel Incorporated Inclined Solar Still-An Experimental Investigation," in Solar Desalination Technology. Green Energy and Technology, A. Kumar and O. Prakash, Eds., pp. 275-292, Springer, Singapore, 2019.

[44] A. M. Manokar, M. Vimala, R. Sathyamurthy, A. E. Kabeel, D. P. Winston, and A. J. Chamkha, "Enhancement of potable water production from an inclined photovoltaic panel absorber solar still by integrating with flat-plate collector," Environment, Development and Sustainability, vol. 22, no. 5, pp. 4145-4167, 2020.

[45] Y. Taamneh, A. M. Manokar, M. M. Thalib, A. E. Kabeel, R. Sathyamurthy, and A. J. Chamkha, "Extraction of drinking water from modified inclined solar still incorporated with spiral tube solar water heater," Journal of Water Process Engineering, vol. 38, p. 101613, 2020.

[46] A. E. Kabeel, R. Sathyamurthy, S. A. El-Agouz, A. M. Manokar, A. Tripathi, and G. B. Abdelaziz, "Experimental investigation of a hybrid setup for distilled water and power production," Desalination and Water Treatment, vol. 162, pp. 30-36, 2019.

[47] A. E. Kabeel, R. Sathyamurthy, A. M. Manokar, S. W. Sharshir, F. A. Essa, and A. H. Elshiekh, "Experimental study on tubular solar still using graphene oxide nanoparticles in phase change material (NPCM's) for fresh water production," Journal of Energy Storage, vol. 28, p. 101204, 2020.

[48] B. I. Ismail, "Design and performance of a transportable hemispherical solar still," Renewable Energy, vol. 34, no. 1, pp. 145150, 2009.

[49] T. Arunkumar, R. Jayaprakash, D. Denkenberger et al., “An experimental study on a hemispherical solar still," Desalination, vol. 286, pp. 342-348, 2012.

[50] G. N. Tiwari and S. A. Lawrence, "New heat and mass transfer relations for a solar still," Energy Conversion and Management, vol. 31, no. 2, pp. 201-203, 1991.

[51] G. N. Tiwari, V. Dimri, and A. Chel, "Parametric study of an active and passive solar distillation system: energy and exergy analysis," Desalination, vol. 242, no. 1-3, pp. 1-18, 2009. 